\title{
The Level of Reactive Carbonyl Derivatives of Proteins, Methylglyoxal, and Malondialdehyde in Rats Experiencing Chronic Unpredictable Moderate Stress
}

\author{
Yelena Valerievna Yepifantseva ${ }^{1 *}$, Larisa Yevgenyevna Muravlyova ${ }^{2}$, Polina Sergeyevna Semenikhina ${ }^{1}$, \\ Mariya Andreevna Romanova ${ }^{3}$, Roza Battalovna Seidakhmetova ${ }^{3}$, Amirzhan Muratovich Smagulov ${ }^{1}$,
} Sultanbek Meiramovich Amanzholov ${ }^{1}$, Rustam Oryngaliyevich Tuleuov ${ }^{1}$

${ }^{1}$ Department of Neurology, Neurosurgery, Psychiatry and Rehabilitation, Karaganda Medical University, Karaganda, Kazakhstan; ${ }^{2}$ Department of Biological Chemistry, Karaganda Medical University, Karaganda, Kazakhstan; ${ }^{3}$ Laboratory of Pharmacology, Phytochemistry International Scientific and Production Holding JSC, Karaganda, Kazakhstan

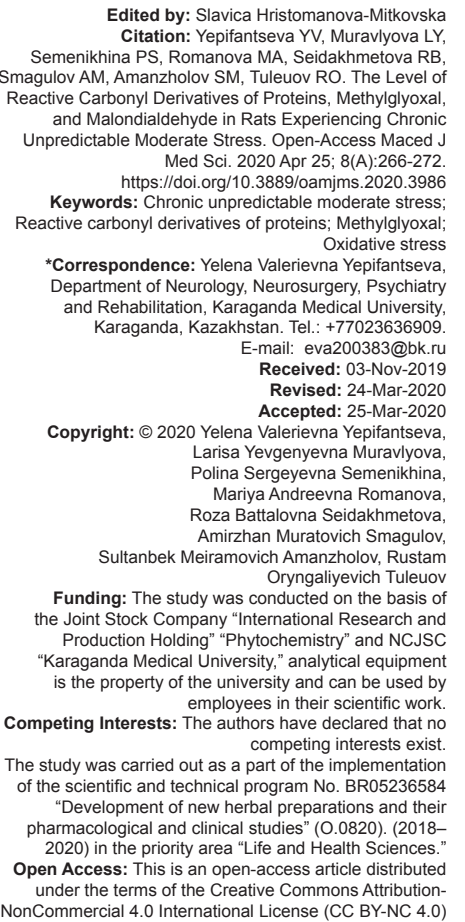

\section{Abstract}

BACKGROUND: Prolonged exposure to stress is known to change homeostasis and can lead to the development of psychopathological disorders, including depression. Exposure to stress factors contributes to the emergence of reactive oxygen species in the brain. The data characterizing changes of the oxidative metabolism under conditions of chronic stress are insufficient, which determine the relevance of the research in this direction. The determination of reactive carbonyl derivatives of proteins (RCDP), methylglyoxal (MG), and malondialdehyde (MDA) levels can be considered an informative method for studying the dynamics of oxidative metabolism.

AIM: The aim of the study was to study the RCDP, MG, and MDA in red blood cells and blood plasma in rats experiencing chronic unpredictable moderate stress (CUMS).

METHODS: A total of 20 male outbred rats weighing 450-500 g were used in the study. The animals were divided into two groups of ten rats each using randomized selection. The experimental group of animals was exposed to the impact of diverse stress factors, according to the CUMS model for 21 days. The control group of animals remained in standard conditions and did not undergo CUMS model. Blood sampling was performed twice for all rats the day before the experiment started and on $21^{\text {st }}$ day to determine the level of RCDP, MG, and MDA in their erythrocytes and blood plasma.

RESULTS: The study revealed a significant decrease of RCDP $(p=0.007)$ and MDA levels in erythrocytes $(p=$ $0.013)$, and MDA level in blood plasma $(p=0.005)$ of rats of the main experimental group. The control group showed a significant increase of RCDP level in plasma $(p=0.008)$, a two-fold increase of MDA in erythrocytes $(p=0.05)$ with a decrease of MDA in plasma $(p=0.011)$. A tendency for MG increase was noted in erythrocytes of rats in both the main group and the control group.

CONCLUSION: The early stages of CUMS were accompanied by the violation of oxidative metabolism with the emergence and accumulation of RCDP and MDA in the blood of animals. The decreased emergence of RCDP and MDA in the later stages can be associated with an excess of oxidized substrates in the blood of animals of the experimental group. The revealed trend toward MG growth in animals of both groups suggests its increased synthesis in erythrocytes, which, in our opinion, should be considered a negative factor affecting the deformability of red cells. In turn, a violation of the deformability of red blood cells leads to a violation of microcapillary blood flow, which contributes to the development of hypoxic damage in different tissues. Thus, the obtained data confirm the different directions of changes in RCDP and MDA levels in the blood of animals experiencing CUMS or acute stress. Our results prove the need for further research on changes in oxidative metabolism in chronic stress disorders.

\section{Introduction}

Stress is considered one of the important causes of somatic and mental pathology, including adaptation disorders [1], [2]. Enough data have been obtained confirming the direct relation of stress with the development of depression [3], [4]. Stress changes homeostasis, affects the neuroendocrine and immune systems, and leads to the evolvement of psychopathological syndromes [5], [6].
Reactionstoacutestress(AS)and chronicstress suggest various biochemical changes and subsequent behavioral disorders. It has been established that under the influence of stress factors the level of reactive oxygen species in the brain increases [7], [8]. Separate sporadic studies demonstrate certain differences in the direction of the oxidative metabolism reactions in tissues during acute and chronic stress [9].

The mechanism of influence of chronic stress is of greatest interest to researchers. Chronic stress is known to trigger the release mechanism for a significant 
number of neurotransmitters with the formation of a pro-inflammatory response of microglia and to cause structural changes in neuroglia [10], [11], [12]. Chronic stress alters the expression of genes that regulate antioxidant enzymes such as catalase, glutathione peroxidase, nicotinamide adenine dinucleotide phosphate (NADPH) oxidase, superoxide dismutase, and glutathione reductase [13], [14], [15]. Activation of lipid peroxidation and inhibition of the mitochondrial respiratory chain are shown in the model of chronic immobilization stress [16]. A study of patients with depression and bipolar disorder revealed a decrease in antioxidant protection and an increase in the level of lipid peroxidation in blood [17], [18]. A new meta-analysis confirmed an increased level of 8-hydroxy-2'-deoxyguanosine and F2-isoprostanes in tissues and biological fluids, marking increased oxidative damage to DNA and lipids in patients with bipolar disorder and various types of depression [19].

Changes in oxidative metabolism under the influence of chronic stress are an important aspect of understanding its damaging effects. Studies show changes in levels of oxidative stress markers in mental and neurological pathologies. An increase in the level of malondialdehyde (MDA) and the number of carbonyl groups is recorded in cerebral ischemia [20]. The damaging effect of methylglyoxal (MG) is mediated by the formation of MG-modified proteins with the development of carbonyl stress in neuroblastomas [21]. The process of inactivation of proteins by the oxygen active species is a direct factor in the development of carbonyl stress with the succeeding progression of neurodegenerative disorders [22], [23], [24]. A significant number of researchers conducted studies of isolated indicators of carbonyl stress or its end products in the already evolved pathological conditions. However, according to available data, exposure to chronic stress leads to activation of oxidative stress mechanisms with stimulation of the "hypothalamus-pituitary-adrenal gland" chain reaction with ensuing systemic damage [25]. Thus, the study of neuron-specific markers and isolated fractions of carbonyl proteins in our study were not justified, while reactive carbonyl derivatives of proteins (RCDP), MG, and MDA could be considered the most informative indicators of oxidative stress and can be used as markers of oxidative damage at the stage of pathology formation and as a control for further therapy.

An analysis of the literature data showed, that markers of the state of oxidative metabolism, such as RCDP, MG, and MDA, have hardly been studied under conditions of chronic stress, which explains the relevance of this study.

Protein carbonylation is a common protein modification mechanism. Carbonyl derivatives can appear in different ways: As a result of direct oxidation of the amino acid residues of lysine, arginine, proline and threonine, or under the action of reactive oxygen species, as well as in reactions with carbonyl-containing oxidized lipids. Other carbonylation pathways include protein fragmentation, a-amidation, and oxidation of glutamine side chains [26]. Protein carbonylation is an irreversible process leading to a loss of proteins' functions. Under physiological conditions carbonylation plays an important role in protein quality control and protein metabolism. Increased carbonylation leads to accumulation of proteolysis-resistant aggregates of oxidized proteins [27]. Some of neurodegenerative diseases are associated with the accumulation of carbonylated protein aggregates in cells and tissues [28].

MG appears mainly in the process of glycolysis from glyceroaldehyde-3-phosphate and dioxiaacetonphosphate. The utilization of MG into D-lactate occurs through the glyoxylase system with the participation of reduced glutathione. The pentose phosphate pathway is also involved in the metabolism of MG as a source of NADPH, which is necessary for the reduction of oxidized glutathione. MG is a highly reactive dicarbonyl, capable of forming adducts with proteins and nucleic acids, leading to the loss of their biological functions [29].

MDA is the product of arachidonic acid and other polyunsaturated fatty acids decomposition and appears as a result of enzymatic and non-enzymatic reactions. The functions of MDA are currently under active study. It is known that MDA can work as a signal messenger, as well as regulate the expression of a number of genes. On the other hand, MDA is able to form adducts with proteins and DNA, which leads to disruption of their structure and loss of biological functions [30].

The aim of our study is to examine changes in the levels of RCDP, MG, and MDA in red blood cells and blood plasma in rats experiencing chronic unpredictable moderate stress (CUMS).

\section{Methods}

To reproduce the conditions of chronic stress, a model that met the criteria of credibility and reliability was selected. In recent years, the model of "CUMS" has confirmed its position as a reference model for the study of the neurobiological basis of stress-induced disorders and the development of new antidepressants [31], [32], [33].

\section{Selection and description of participants}

A total of 20 male outbred rats weighing 450 $500 \mathrm{~g}$. were used in the study. The animals were kept (five rats per cage) under standard laboratory conditions (25 $\pm 2^{\circ} \mathrm{C}$, humidity $60-70 \%$ ), maintaining a $12-\mathrm{h}$ natural day-night cycle with free access to standard food and water. The quarantine and keeping conditions of the animals before the start of the experiment met 
the established requirements. The rats were divided into two groups ten animals each using randomized selection. The study was conducted in accordance with the requirements of the European Convention for the Protection of Vertebrate Animals Used in Experiments and Other Scientific Purposes (Strasbourg, 1986), requirements of GLP OECD, EAEU Rules of Good Laboratory Practice No. 81, order of the Ministry of Health and Social Development of the Republic of Kazakhstan No. 392 dated May 25, 2015. The study was approved by the decision of the Committee on Bioethics of the Karaganda Medical University on June 17, 2019, protocol No. 65.

\section{Technical information}

The experimental group of animals was exposed to the CUMS, while the comparison control group was kept in standard conditions without CUMS. Animals of the two groups underwent behavioral testing and blood sampling procedure. Thus, the animals of the control group can be considered an animal model of AS, which was caused in animals 4 times during the study period.

\section{Behavioral assessments}

Animals of the two groups were tested according to the standard protocols in the "open field test" [34], "the elevated cross-maze test" [35], "tailhanging test" [36], [37], and "sucrose preference test" [38]. Behavioral tests were performed on the day preceding the start of the experiment, designated as first control point, and at the end of each cycle of the CUMS model, which corresponded to the $7^{\text {th }}, 14^{\text {th }}$, and $21^{\text {st }}$ days of the experiment. The day of the behavioral tests additional stress factors were absent, since the animals were placed into the new environment for the behavioral testing and that can be considered as a stressful factor itself. A rest period of $1 \mathrm{~h}$ was allowed in between each trial.

Animals in two groups underwent the blood sampling from the tail vein, blood being gathered into heparinized tubes. The procedure was performed under light ether anesthesia on the day preceding the start of the experiment, designated as first control point, and on the $21^{\text {st }}$ day of the experiment, designated as a second control point. Blood sampling in animals was carried out after behavioral testing, since the blood sampling procedure and the effects of ether anesthesia could have affected the results of behavioral tests and had been a significant stress factor.

\section{Experimental procedure for CUMS model}

For 21 days, the animals of the main experimental group were experiencing the trials according to the "CUMS" model, presented in Table 1 (three cycles of 7 days each).

Table 1: Exposure schedule for rats of the main group, leading to formation of the chronic unpredictable moderate stress model

\begin{tabular}{|c|c|c|c|c|c|c|}
\hline Type of & Day of exper & riment cycle & & & & Control test \\
\hline exposure & 12 & 3 & 4 & 5 & 6 & \\
\hline Narrow cell & $12.00-08.00$ & & & & & $\begin{array}{l}\text { Behavioral } \\
\text { tests }\end{array}$ \\
\hline $\begin{array}{l}\text { Food } \\
\text { deprivation }\end{array}$ & $8.00-$ & -08.00 & & & & \\
\hline $\begin{array}{l}\text { Immobilization } \\
\text { in a case }\end{array}$ & & $10.00-14.00$ & & & & \\
\hline $\begin{array}{l}\text { Shading during } \\
\text { daylight hours }\end{array}$ & & & $6.00-21.00$ & & & \\
\hline $\begin{array}{l}\text { Water } \\
\text { deprivation }\end{array}$ & & & & $8.00-18.00$ & & \\
\hline $\begin{array}{l}\text { Artificial light } \\
\text { during night } \\
\text { hours }\end{array}$ & & & & $19.00-10.00$ & & \\
\hline $\begin{array}{l}\text { Full } \\
\text { immobilization }\end{array}$ & & & & & $10.00-12.00$ & \\
\hline
\end{tabular}

Types of exposure used to form the CUMS model:

- Narrow cell - limiting the space of the cell by half due to the installation of an additional partition in the cell

- $\quad$ Food deprivation - food deprivation for $24 \mathrm{~h}$

- Immobilization in a case - animals are placed in individual cases, which do not deprive them of the ability to move, but greatly limit the space for movement

- $\quad$ Shading during daylight hours - artificial dimming during daylight hours, lasting $15 \mathrm{~h}$ Water deprivation - deprivation of water for $10 \mathrm{~h}$ Artificial light during night hours - creating artificial lighting in the nighttime hours, lasting $15 \mathrm{~h}$

Full immobilization - placing animals in individual canisters, depriving them of the ability to move for $2 \mathrm{~h}$.

\section{Spectrophotometric study}

Blood samples obtained during the study were transferred to the laboratory, where they underwent centrifugation and analysis of the collected materials by spectrophotometry using a PD-303 ultraviolet (UV) digital UV-VIS spectrophotometer, manufactured by APEL, Japan.

\section{Determining RCDP}

We measured the concentration of RCDP following the well-tested protocol of Levine et al. [39], [40]. To triplicate aliquots of plasma $(0.8 \mathrm{~mL})$, we added $0.2 \mathrm{~mL}$ of $10 \%$ trichloroacetic acid solution and centrifuged the samples. Then, either $1 \mathrm{~mL}$ of $2 \mathrm{M} \mathrm{HCl}$ liquid solution or $10 \mathrm{~mL}$ of 2.4-dinitrophenylhydrazine (DNPH) in $2 \mathrm{M} \mathrm{HCl}$ solution was added to the precipitates, and further this mixture was incubated at $37^{\circ} \mathrm{C}$ for $90 \mathrm{~min}$. Next, the samples were centrifuged again (8000 rpm, $10 \mathrm{~min}$ ) and the DNPH excess was removed with ethanol-ethyl acetate $1: 1(\mathrm{v} / \mathrm{v})$. Finally, the samples were re-suspended 
in $6 \mathrm{M}$ of guanidine hydrochloride. Quantification was performed using a spectrophotometer PD - 303 UV APEL (Japan) at a $366 \mathrm{~nm}$ absorbance. Concentration of carbonyl derivatives was calculated using the molar absorption coefficient of 22,000 mol/ $\mathrm{cm}^{-1}$, RCDP values were given in $\mathrm{nmol} / \mathrm{ml}$.

\section{Determining MGs}

MG was determined by reaction with dinitrophenylhydrazine according to a modified Racker method [41]. We combined $25 \mu \mathrm{l}$ of blood sample with $350 \mu \mathrm{l}$ of DNPH $(0.1 \% \mathrm{DNPH}$ in $2 \mathrm{~N} \mathrm{HCl})$ and then added $2.125 \mathrm{~mL}$ of distilled water to each tube. Finally, we incubated samples for $15 \mathrm{~min}$ at $37^{\circ} \mathrm{C}$ and after the incubation added $1.5 \mathrm{~mL}$ of $10 \% \mathrm{NaOH}$. The absorbance for spectrophotometer was set at $576 \mathrm{~nm}$; MG levels were expressed in percent absorbance of MG.

\section{Determining MDA}

MDA in red blood cells was determined according to the protocol of Goncharenko and Latypova [42]. To determine MDA, erythrocytes were washed in $10 \mathrm{~mL}$ of chilled saline, and then centrifuged for $10 \mathrm{~min}$ at $3000 \mathrm{rpm}$. The washed red blood cells were hemolyzed with distilled water with a $1: 5$ ratio. For the study, we took $0.3 \mathrm{~mL}$ of hemolysate, added $0.3 \mathrm{~mL}$ of $10 \%$ phosphotungstic acid and $10 \mathrm{~min}$ later centrifuged the samples at $3000 \mathrm{rpm}$ for $10 \mathrm{~min}$. The resulting precipitate was washed with $1 \mathrm{~mL}$ of distilled water and centrifuged once again. Then, $3 \mathrm{~mL}$ of water and $1 \mathrm{~mL}$ of thiobarbituric acid $(80 \mathrm{mg}$ of tert-butyl alcohol in a mixture of $5 \mathrm{~mL}$ of water and $5 \mathrm{~mL}$ of acetic acid) were added to the precipitate and incubated for $60 \mathrm{~min}$ in a boiling water bath. Finally, the solution was centrifuged and tested for absorbance at spectrophotometer set at $532 \mathrm{~nm}$ against water. In the calculations, we used the molar extinction coefficient, which is $1.56 \times 10^{5} \mathrm{M} / \mathrm{cm}^{-1}$ expressed in $\mu \mathrm{mol} / \mathrm{mL}$.

\section{Statistics}

The results were statistically processed using the SPSS.Statistics.v22. multilingual-EQUiNOX (SPSS Inc.) software.

Analysis of the obtained data was conducted using descriptive statistics. The comparison of oxidized metabolism before and after the experiment was carried out using the non-parametric Wilcoxon t-test $(\alpha=0.05)$. points (a day before the experiment and $21^{\text {st }}$ day of the experiment), the non-parametric Wilcoxon t-test $(\alpha=0.05)$ was used, where statistically significant differences were accepted at $p \leq 0.05$.

The results of studies in the main group, presented in Table 2, show a reliably significant decrease of RCDP level in erythrocytes by 1.67 times (median, $p=0.007)$, MDA level in plasma $(p=0.005)$, and MDA level in erythrocytes $(p=0.013)$ on the $21^{\text {st }}$ day of the experiment. A tendency toward a decrease in RCDP level in blood plasma and MG level in erythrocytes of rats of the main group was also revealed.

Table 2: RCDP, MDA levels in plasma and RCDP, MDA, MG levels in erythrocytes in the main group

\begin{tabular}{llll}
\hline Indicator & $\begin{array}{l}\text { Median (Q25; Q75) } \\
\text { before the experiment }\end{array}$ & $\begin{array}{l}\text { Median }(\mathrm{Q} 25 ; \mathrm{Q} 75) \\
\text { after the experiment }\end{array}$ & $\mathrm{p}$ \\
\hline RCDP in erythrocytes & $10,74(9,498 ; 12,81)$ & $6,403(3,939 ; 8,866)$ & 0,007 \\
MDA in erythrocytes & $10,00(8,846 ; 10,90)$ & $9,231(8,077 ; 19,49)$ & 0,013 \\
MG in erythrocytes & $0,615(0,573 ; 0,639)$ & $0,757(0,728 ; 0,828)$ & 0,445 \\
RCDP in plasma & $1,052(0,857 ; 1,134)$ & $0,996(0,848 ; 1,212)$ & 0,878 \\
MDA in plasma & $1,720(1,694 ; 1,774)$ & $1,548(1,350 ; 1,668)$ & 0,005 \\
\hline MG: Methylglyoxal, RCDP: Reactive carbonyl derivatives of proteins, MDA: Malondialdehyde.
\end{tabular}

Table 3 shows the results of a study of the target parameters in the blood of rats of the comparison group. On the $21^{\text {st }}$ day of the experiment, there was a significant increase of RCDP level in plasma $(p=0.008)$ and MDA in erythrocytes twice from the initial level $(p=0.05)$, while MDA in plasma decreased $(p=0.011)$. There also was a tendency toward an increase of RCDP and MG levels in the erythrocytes of rats of the comparison group.

Table 3: RCDP, MDA levels in plasma and RCDP, MDA, MG levels in erythrocytes in the comparison group

\begin{tabular}{llll}
\hline Indicator & $\begin{array}{l}\text { Median (Q25; Q75) } \\
\text { before the experiment }\end{array}$ & $\begin{array}{l}\text { Median }(\mathrm{Q} 25 ; \mathrm{Q} 75) \\
\text { after the experiment }\end{array}$ & $\mathrm{p}$ \\
\hline RCDP in erythrocytes & $1.983(1.792 ; 2.121)$ & $2.424(1.662 ; 3.013)$ & 0.441 \\
MDA in erythrocytes & $6.795(5.769 ; 8.077)$ & $13.97(8,718 ; 21.54)$ & 0.050 \\
MG in erythrocytes & $0.787(0.758 ; 0.897)$ & $0.807(0.676 ; 0.831)$ & 0.575 \\
RCDP in plasma & $0.628(0.606 ; 0.753)$ & $1.377(1.117 ; 1.411)$ & 0.008 \\
MDA in plasma & $2.250(1.694 ; 2.833)$ & $1.482(1.376 ; 1.508)$ & 0.011 \\
\hline MG: Methylglyoxal, RCDP: Reactive carbonyl derivatives of proteins, MDA: Malondialdehyde.
\end{tabular}

The results of the study show that the levels of RCDP and MDA are reduced in blood plasma and in erythrocytes of the animals experiencing CUMS. At the same time, in animals with AS the revealed changes in the studied parameters have the opposite direction, which are documented by an increase in the content of RCDP in blood plasma and erythrocytes and MDA in erythrocytes. At the same time, a decrease of MDA level in the blood plasma of animals with an AS factors was recorded. In other words, we found that oxidative stress markers levels change in opposite directions depending on the type of stress factors exposure.

\section{Results}

To compare the studied parameters in blood plasma and erythrocytes on the first and second control

\section{Discussion}

According to the generally accepted theory of the effect of stress on the body, the development 
of stress-induced disorders directly depends on the adaptation mechanisms, duration, and strength of the stress factor influence and neurobiological vulnerability to behavioral disorders [32]. Available studies indicate that each stress model has a different effect on the tissues of various organs [43]. These assumptions are confirmed in our study. The data obtained from the study of animals in the model of chronic stress show predominant damage in red blood cells, which may explain, among other things, damage to the central nervous system with the formation of stress-induced disorders. The study of the mechanisms of the stress, affecting biochemical processes through a change in the oxidative modification of proteins and lipid peroxidation, still continues.

In our experiment, the CUMS and AS models were used to form chronic and AS-induced disorders. The CUMS model implies daily exposure to unpredictable stress factors of small strength. In addition, behavioral reactions were studied in animals of this group.

In the AS model, the animals were not subjected to daily stress exposure of low strength, but they were tested in behavioral tests. The behavioral assessment procedure included a "tail suspension test," which in itself can be considered as a rather traumatic, if AS factor [44].

Our results of assessing the RCDP and MDA levels allowed us to conclude that the development of carbonyl stress in the blood and the activation of lipid peroxidation in rat blood with a model of AS happen simultaneously. At the same time, a decrease of RCDP and MDA levels was observed on the $21^{\text {st }}$ day of the experiment in the blood of rats experiencing CUMS. In our opinion, the following assumption can be made as a hypothesis: In all likelihood, the early stages of CUMS were accompanied by the violation of oxidative metabolism with the emergence and accumulation of RCDP and MDA in the blood of animals. The decreased emergence of RCDP and MDA in the later stages can be associated with an excess of oxidized substrates in the blood of animals of the experimental group. The revealed trend toward MG growth in animals of both groups suggests its increased synthesis in erythrocytes, which, in our opinion, should be considered a negative factor affecting the deformability of red cells [45]. In turn, a violation of the deformability of red blood cells leads to a violation of microcapillary blood flow, which contributes to the development of hypoxic damage in different tissues.

When comparing the results in the main group and in the comparison group, various trends of changes after the experiment were revealed. Hence, the concentration of RCPD in the plasma and erythrocytes of rats of the main group showed a pronounced increase after the experiment (by $111 \%$ and $77 \%$, respectively). In the comparison group, such changes were not observed: There was no significant growth in plasma
RCPD level and, contrariwise, even a decrease in the concentration of RCPD by $41 \%$ in red blood cells was noted.

Changes in the concentration of MDA in blood plasma and red blood cells were unidirectional in both groups, but with varying degrees of severity. Hence, in the red blood cells of rats of the main group the concentration of MDA after the experiment increased by $177 \%$, while in the comparison group there was only an increase by $25 \%$. In the blood plasma of rats of the main group a decrease in the concentration of MDA by $40 \%$ was noted, while in the comparison group the decrease in concentration was only at the $15 \%$ level. Changes in the concentration of MG in the blood of rats of the main group were not pronounced, while in the comparison group the concentration increased by $28 \%$. The revealed differences in the results dynamics in the groups demonstrate involvement of the separate oxidative metabolism elements in the various pathological mechanisms of acute and chronic stress formation. According to the results of the obtained data, the predominant accumulation of oxidative metabolites in red blood cells was revealed, which is a factor of subsequent hypoxic tissue damage. The changes in the MG level which does not correlate with the levels of RCDP and MDA, in our opinion, can be explained by its predominant accumulation in tissues, where under the conditions of oxidative stress it mediates the maximum damaging effect. This assumption requires further study of tissue indicators of MG concentration. A significant increase in the level of MDA in red blood cells in the main group, in our opinion, may be a cause of the early death of erythrocytes and the loss of their biological functions due to the high degree of toxicity of the MDA molecule [46]. The accumulation of RCDP in turn contributes to inhibition of mitochondrial respiration function with the development of ensuing tissue hypoxia.

\section{Conclusion}

Thus, the obtained data confirm the different directions of changes in RCDP and MDA levels in the blood of animals experiencing CUMS and AS. Our results prove the need for further research on changes in oxidative metabolism in chronic stress disorders.

\section{References}

1. Hammen C. Stress and depression. Annu Rev Clin Psychol. 2005;1:293-319.

PMid:17716090

2. International Classification of Diseases. Classification of Mental 
and Behavioral Disorders (Clinical Descriptions and Instructions for Diagnosis). Russia: WHO, SPB; 1994. p. 304.

3. Du J, Zhu M, Bao H, Li B, Dong Y, Xiao C, et al. The role of nutrients in protecting mitochondrial function and neurotransmitter signaling: Implications for the treatment of depression, PTSD, and suicidal behaviors. Crit Rev Food Sci Nutr. 2016;56(15):2560-78. https://doi.org/10.1080/10408398.2 013.876960

\section{PMid:25365455}

4. Robinson ME, Teyhen DS, Wu SS, Dugan JL, Wright AC, Childs JD, et al. Mental health symptoms in combat medic training: A longitudinal examination. Mil Med. 2009;174(6):5727. https://doi.org/10.7205/milmed-d-02-4108

PMid:19585767

5. de Paula Brotto MA. Temporal effects of stress by immobilization and sensitivity of the isolated rat pacemaker to isoproterenol: Roles of corticosterone, neuronal uptake, and beta-adrenergic homogeneity. J Pharmacol Exp Ther. 2003;306(3):1152-8. https://doi.org/10.1124/jpet.103.052670

PMid:12829727

6. Tagliari B, Noschang CG, Ferreira AG, Ferrari OA, Feksa LR, Wannmacher $\mathrm{CM}$, et al. Chronic variable stress impairs energy metabolism in prefrontal cortex and hippocampus of rats: Prevention by chronic antioxidant treatment. Metab Brain Dis. 2010;25(2):169-76. https://doi.org/10.1007/s11011-010-9194-x PMid:20505986

7. Manoli LP, Gamaro GD, Silveira PP, Dalmaz C. Effect of chronic variate stress on thiobarbituric-acid reactive species and on total radical-trapping potential in distinct regions of rat brain. Neurochem Res. 2000;25(7):915-21.

PMid: 10959487

8. Fontella FU, Siqueira IR, Vasconcellos AP, Tabajara AS, Netto CA, Dalmaz C. Repeated restraint stress induces oxidative damage in rat hippocampus. Neurochem Res. 2005;30(1):10511. https://doi.org/10.1007/s11064-004-9691-6 PMid: 15756938

9. Liu J, Yeo HC, Overvik-Douki E, Hagen T, Doniger SJ, Chyu DW, et al. Chronically and acutely exercised rats: Biomarkers of oxidative stress and endogenous antioxidants. J Appl Physiol (1985). 2000;89(1):21-8. https://doi.org/10.1152/ jappl.2000.89.1.21

PMid:10904031.

10. Hinwood M, Tynan RJ, Charnley JL, Beynon SB, Day TA, Walker FR. Chronic stress induced remodeling of the prefrontal cortex: Structural re-organization of microglia and the inhibitory effect of minocycline. Cereb Cortex. 2013;23(8):1784-97. https://doi.org/10.1093/cercor/bhs151

PMid:22710611

11. Walker FR, Nilsson M, Jones K. Acute and chronic stressinduced disturbances of microglial plasticity, phenotype and function. Curr Drug Targets. 2013;14(11):1262-76. https://doi. org/10.2174/13894501113149990208

PMid:24020974

12. Tynan RJ, Naicker S, Hinwood M, Nalivaiko E, Buller KM, Pow DV, et al. Chronic stress alters the density and morphology of microglia in a subset of stress-responsive brain regions. Brain Behav Immun. 2010;24(7):1058-68. https://doi.org/10.1016/j. bbi.2010.02.001

PMid:20153418

13. Seo JS, Park JY, Choi J, Kim TK, Shin JH, Lee JK, et al. NADPH oxidase mediates depressive behavior induced by chronic stress in mice. J Neurosci. 2012;32(28):9690-9. https://doi. org/10.1523/jneurosci.0794-12.2012 PMid:22787054

14. Schiavone $S$, Sorce $S$, Dubois-Dauphin $M$, Jaquet $V$,
Colaianna M, Zotti M, et al. Involvement of NOX2 in the development of behavioral and pathologic alterations in isolated rats. Biol Psychiatry. 2009;66:384-92. https://doi.org/10.1016/j. biopsych.2009.04.033

PMid:19559404

15. Grillo CA, Piroli GG, Rosell DR, Hoskin EK, Mcewen BS, Reagan LP. Region specific increases in oxidative stress and superoxide dismutase in the hippocampus of diabetic rats subjected to stress. Neuroscience. 2003;121(1):133-40. https:// doi.org/10.1016/s0306-4522(03)00343-9

PMid:12946706

16. Madrigal JL, Olivenza R, Moro MA, Lizasoain I, Lorenzo P, Rodrigo $\mathrm{J}$, et al. Glutathione depletion, lipid peroxidation and mitochondrial dysfunction are induced by chronic stress in rat brain. Neuropsychopharmacology. 2001;24(4):420-9. https:// doi.org/10.1016/s0893-133x(00)00208-6

PMid:11182537

17. Andreazza AC, Kauer-Sant'anna M, Frey BN, Bond DJ, Kapczinski F, Young LT, et al. Oxidative stress markers in bipolar disorder: A meta-analysis. J Affect Disord. 2008;111(2-3):13544. https://doi.org/10.1016/j.jad.2008.04.013

PMid:18539338

18. Palta P, Samuel LJ, Miller ER $3^{\text {rd }}$, Szanton SL. Depression and oxidative stress: Results from a meta-analysis of observational studies. Psychosom Med. 2014;76(1):12-9. https://doi. org/10.1097/psy.0000000000000009

PMid:24336428

19. BlackCN,BotM,SchefferPG, CuijpersP,PenninBW. Is depression associated with increased oxidative stress? A systematic review and meta-analysis. Psychoneuroendocrinology. 2015;51:16475. https://doi.org/10.1016/j.psyneuen.2014.09.025

PMid:25462890

20. Ya BL, Li HF, Wang HY, Wu F, Xin Q, Cheng HJ, et al. 5-HMF attenuates striatum oxidative damage via Nrf2/ARE signaling pathway following transient global cerebral ischemia. Cell Stress Chaperones. 2017;22(1):55-65. https://doi.org/10.1007/ s12192-016-0742-0

PMid:27812888

21. Nishimoto $S$, Koike $S$, Inoue $N$, Suzuki $T$, Ogasawara $Y$. Activation of Nrf2 attenuates carbonyl stress induced by methylglyoxal in human neuroblastoma cells: Increase in GSH levels is a critical event for the detoxification mechanism. Biochem Biophys Res Commun. 2017;483(2):874-9. https://doi. org/10.1016/j.bbrc.2017.01.024

PMid:28073699

22. Ogłodek EA. Evaluation of ADMA, carbonyl groups, CAT and NKA in depressed patients with and without posttraumatic stress disorder. Pharmacol Rep. 2017;69(4):730-7. https://doi. org/10.1016/j.pharep.2017.02.015

PMid:28554099

23. Nosareva OL, Stepovaya EA, Ryazantseva NV, Shakhristova EV, Egorova MY, Novitsky VV. The role of the glutathione system in oxidative modification of proteins and dysregulation of apoptosis in jurkat tumor cells. Bull Exp Biol Med. 2017;164(2):199-202. https://doi.org/10.1007/s10517-017-3957-x

PMid:29177874

24. Zhang $X$, Li Z, Zhang Q, Chen L, Huang $X$, Zhang $Y$, et al. Mechanisms underlying $\mathrm{H} 2 \mathrm{O} 2-$ evoked carbonyl modification of cytoskeletal protein and axon injury in PC-12 cells. Cell Physiol Biochem. 2018;48(3):1088-98. https://doi. org/10.1159/000491975

PMid:30041238

25. Dominguez G, Henkous N, Prevot T, David V, Guillou JL, Belzung $\mathrm{C}$, et al. Sustained corticosterone rise in the prefrontal cortex is a key factor for chronic stress-induced working memory 
deficits in mice. Neurobiol Stress. 2019;10:100161. https://doi. org/10.1016/j.ynstr.2019.100161

PMid:31309134

26. Gryszczyńska B, Formanowicz D, Budzyń M, WanicKossowska M, Pawliczak E, Formanowicz P, et al. Advanced oxidation protein products and carbonylated proteins as biomarkers of oxidative stress in selected atherosclerosismediated diseases. Biomed Res Int. 2017;2017:4975264. https://doi.org/10.1155/2017/4975264

27. Nyström T. Role of oxidative carbonylation in protein quality control and senescence. EMBO J. 2005;24(7):1311-7. https:// doi.org/10.1038/sj.emboj.7600599 PMid: 15775985

28. Dalle-Donne I, Aldini G, Carini M, Colombo R, Rossi R, Milzani A. Protein carbonylation, cellular dysfunction, and disease progression. J Cell Mol Med. 2006;10(2):389-406. https://doi.org/10.1111/j.1582-4934.2006.tb00407.x PMid:16796807

29. Allaman I, Bélanger M, Magistretti PJ. Methylglyoxal, the dark side of glycolysis. Front Neurosci. 2015;9:23. https://doi. org/10.3389/fnins.2015.00023 PMid:25709564

30. Ayala A, Muñoz MF, Argüelles S. Lipid peroxidation: Production, metabolism, and signaling mechanisms of malondialdehyde and 4-hydroxy-2-nonenal. Oxid Med Cell Longev. 2014;2014:360438. https://doi.org/10.1155/2014/360438 PMid:24999379

31. Willner P. The chronic mild stress (CMS) model of depression: History, evaluation and usage. Neurobiol Stress. 2017;6:78-93. https://doi.org/10.1016/j.ynstr.2016.08.002 PMid:28229111

32. Hill MN, Hellemans KG, Verma P, Gorzalka BB, Weinberg J. Neurobiology of chronic mild stress: Parallels to major depression. Neurosci Biobehav Rev. 2012;36(9):2085-117. https://doi.org/10.1016/j.neubiorev.2012.07.001 PMid:22776763

33. Willner P, Scheel-Kruger J, Belzung C. The neurobiology of depression and antidepressant action. Neurosci Biobehav Rev. 2013;37:2331-71. https://doi.org/10.1016/j. neubiorev.2012.12.007 PMid:23261405

34. Kuniishi H, Ichisaka S, Yamamoto M, Ikubo N, Matsuda S, Futora $\mathrm{E}$, et al. Early deprivation increases high-leaning behavior, a novel anxiety-like behavior, in the open field test in rats. Neurosci Res. 2017;123:27-35. https://doi.org/10.1016/j. neures.2017.04.012

PMid:28450152

35. Bakhtiyarova ShK, Kapysheva UN, Ablaykhanova NT, Baimbetova AK, Zhaksymov BI, Korganbayeva AA, et al. Behavior of animals in various tests. Int $\mathrm{J}$ Appl Basic Res. 2017;8-1:92-6.

36. Zhu W, Gao Y, Chang CF, Wan JR, Zhu SS, Wang J. Mouse models of intracerebral hemorrhage in ventricle, cortex, and hippocampus by injections of autologous blood or collagenase.
PLoS One. 2014;9:e97423. https://doi.org/10.1371/journal. pone. 0097423

PMid:24831292

37. Cryan JF, Mombereau C, Vassout A. The tail suspension test as a model for assessing antidepressant activity: Review of pharmacological and genetic studies in mice. Neurosci Biobehav Rev. 2005;29:571-625. https://doi.org/10.1016/j. neubiorev.2005.03.009

PMid: 15890404

38. Fernandez JW, Grizzell JA, Philpot RM, Wecker L. Postpartum depression in rats: Differences in swim test immobility, sucrose preference and nurturing behaviors. Behav Brain Res. 2014;272:75-82. https://doi.org/10.1016/j.bbr.2014.06.041 PMid:24983658

39. Levine RL, Williams JA, Stadtman ER, Shacter E. Carbony assays for determination of oxidatively modified proteins. Methods Enzymol. 1994;233:346-57. https://doi.org/10.1016/ s0076-6879(94)33040-9

PMid:8015469

40. Levine RL, Garland D, Oliver CN, Amici A, Climent I, Lenz AG, et al. Determination of carbonyl content in oxidatively modified proteins. Methods Enzymol. 1990;186:464-78. https://doi. org/10.1016/0076-6879(90)86141-h

\section{PMid:1978225}

41. Husna AH, Ramadhani EA, Eva DT, Yulita AF, Suhartono E. The role formation of methylglyoxal, carbonyl compound, hydrogen peroxide and advance oxidation protein product induced cadmium in ovarian rat. Int J Chem Eng Appl. 2014;5(4):319-23. https://doi.org/10.7763/ijcea.2014.v5.402

42. Goncharenko MS, Latypova AM. Method for assessing lipid peroxidation. Labor Case. 1985;1:60-1.

43. Sahin E, Gümüşlü S. Stress-dependent induction of protein oxidation, lipid peroxidation and anti-oxidants in peripheral tissues of rats: Comparison of three stress models (immobilization, cold and immobilization-cold). Clin Exp Pharmacol Physiol. 2007;34(5-6):425-31. https://doi. org/10.1111/j.1440-1681.2007.04584.x

PMid: 17439411

44. Steru L, Chermat R, Thierry B, Simon P. The tail suspension test: A new method for screening antidepressants in mice. Psychopharmacology (Berl). 1985;85(3):367-70. https://doi. org/10.1007/bf00428203 PMid:3923523

45. Iwata $H$, Ukeda $H$, Maruyama $T$, Fujino $T$, Sawamura $M$. Effect of carbonyl compounds on red blood cells deformability. Biochem Biophys Res Commun. 2004;321(3):700-6. https://doi. org/10.1016/j.bbrc.2004.07.026 PMid:15358163

46. Rio Dd, Stewart AJ, Pellegrini N. A review of recent studies on malondialdehyde as toxic molecule and biological marker of oxidative stress. Nutr Metab Cardiovasc Dis. 2005;15(4):316-28. PMid:16054557 